\title{
LAYANAN BERBASIS LOKASI DALAM SISTEM INFORMASI DAN RUTE RUMAH SAKIT DI KOTA KEDIRI
}

\author{
Patmi Kasih $^{1}$, Dwi Harini ${ }^{2}$ \\ 1) Teknik Informatika, Fakultas Teknik, Universitas Nusantara PGRI Kediri \\ ${ }^{2)}$ Sistem Informasi, Fakultas Teknik, Universitas Nusantara PGRI Kediri \\ Kampus 2, Mojoroto Gang 1 No. 6 Kediri \\ E-mail:fatkasih@gmail.com
}

\begin{abstract}
Abstrak
Layanan informasi berbasis lokasi (Location Based Servicel LBS) sudah menjadi suatu kebutuhan yang mengiringi aktivitas masyarakat sehari-hari dalam penyajian informasi yang akurat, khususnya bagi masyarakat yang sangat membutuhkan informasi tertentu dalam kondisi yang mendesak. Demikian juga kebutuhan informasi mengenai rumah sakit dan fasilitas yang disediakan oleh rumah sakit. Sumber informasi tentang rumah sakit sangat diperlukan untuk mengetahui ketersediaan fasilitas di rumah sakit, terutama mengenai dokter ahli dan penyakit yang bisa ditangani. Dalam fungsinya sebagai pendukung layanan GPS (Global Position System) dalam mencari suatu tempat atau lokasi, LBS sangat mendukung fungsi sistem informasi dan rute rumah sakit yang dibangun dalam penelitian ini. Dengan keunggulan dari LBS sebagai gabungan konsep baru Teknologi Informasi dan Komunikasi seperti sistem telekomunikasi selular dan perangkat mobile, dari internet dan dari Sistem Informasi Geografis (GIS) dengan database spasial, diharapkan sistem informasi yang dibangun dapat memberikan manfaat yang maksimal bagi masyarakat. Dalam sistem yang dibangun, informasi tentang rumah sakit yang di berikan meliputi alamat, nomor telepon, e-mail, webside, nama dokter dan penyakit yang ditangani, serta rute menuju rumah sakit.
\end{abstract}

Kata Kunci: Rumah Sakit, Global Position System (GPS), Mobile Android, Location Based Service (LBS)

\section{PENDAHULUAN}

\subsection{Latar Belakang}

Pemanfaatan layanan informasi berbasis lokasi (Location Based Service/ LBS) sudah menjadi suatu kebutuhan yang mengiringi aktivitas masyarakat sehari-hari. Berkembangnya bisnis layanan transportasi, seperti Go-Jek, Go-Car, Grab dan sejenisnya, serta layanan lain yang disediakan oleh manajemen yang sama memanfaatkan layanan informasi berbasis lokasi (Location Based Service) $L B S$ ). Untuk memanfaatkan layanan tersebut maka diperlukan smarthphone yang dapat mengakses aplikasi yang dibutuhkan. Sedangkan aplikasi yang dibuat untuk keperluan layanan $L B S$ haruslah aplikasi yang mendapatkan dukungan google maps. Untuk itu dibutuhkan sistem/ aplikasi dengan bahasa pemrograman/ perangkat lunak yang dapat berjalan dalam smartphone/ android dengan versi yang mendapatkan dukungan penuh dari google.

Ketepatan dalam memilih rumah sakit dan jarak tempuh sangat penting, mengingat wilayah Kota Kediri yang cukup luas, terutama jika dalam keadaan darurat. Banyaknya rumah sakit dan minimnya informasi tentang rumah sakit di Kota Kediri membuat informasi yang sudah ada di anggap kurang (depkes.go.id tahun 2013), sehingga diperlukan suatu sistem informasi yang menyajikan informasi rumah sakit seperti alamat, nomor telepon, e-mail, webside, jenis penyakit apa yang ditangani dan nama dokter yang ada di rumah sakit tersebut.

\subsection{Permasalahan}

Aplikasi Android yang sekarang ini tersedia untuk penggunaan Global Position System (GPS) sebagian besar belum memiliki fungsi yang lengkap (ispytic.com tahun 2016). Dimana pada satu aplikasi memiliki kelebihan A, dan diaplikasi lainnya memiliki kelebihan B. Pada aplikasi pencarian rumah sakit misalnya, aplikasi android yang berfungsi untuk membantu kita menemukan rumah sakit dari posisi pengguna berdasarkan GPS (Global Position System) sebenarnya sudah banyak. Namun dari aplikasi yang ada, belum ada aplikasi yang benar-benar rinci dalam membantu kita mencari rumah sakit, seperti melakukan pencarian rumah sakit sesuai permintaan di Kota Kediri, penyaringan berdasarkan penyakit yang ditangani dan nama dokter yang ada di rumah sakit tersebut, serta memberikan sebuah link rumah sakit untuk mengetahui lebih lengkap fasilitas yang ada di rumah sakit. Aplikasi ini tentunya didukung dengan menggunakan layanan GPS (Global Position System) yang berbasis Android dan terkoneksi langsung dengan internet untuk melihat rute yang akan ditempuh ke lokasi rumah sakit terdekat atau sesuai permintaan.

\subsection{Tujuan}

Tujuan penelitian ini adalah: memberikan suatu sistem bantu yang menyajikan informasi tentang rumah sakit mengenai ketersediaan fasilitas di rumah sakit, terutama mengenai dokter ahli dan penyakit yang bisa ditangani sekaligus rute rumah sakit yang ada di Kota Kediri, sehingga 
memudahkan masyarakat sebagai pengguna untuk mempercepat durasi waktu percarian lokasi rumah sakit pada saat kondisi darurat. Selain itu memudahkan masyarakat untuk memilih rumah sakit sesuai permintaan atau kebutuhan. Aplikasi ini akan memberikan beberapa informasi umum rumah sakit. Informasi-informasi yang diberikan antara lain adalah alamat rumah sakit, nomor telepon rumah sakit, e-mail rumah sakit, penyakit yang ditangani, nama dokter, dan rute terdekat yang dapat dilalui.

\subsection{Metodologi}

Metodologi penelitian ini digunakan sebagai pedoman peneliti dalam pelaksanaan penelitian agar hasil yang dicapai tetap mengarah ke tujuan awal. Metode penelitian yang digunakan dalam penelitian ini adalah:

a. Metode Analisis

Metode analisis yang digunakan:

1) Studi literatur

Metode analisa yang menggunakan suatu cara dengan mempelajari buku-buku, artikel dan jurnal untuk mendapatkan landasan dasar dalam panelitian dan penulisan skripsi.

2) Analisis aplikasi sejenis

Menganalisa atau mempelajari aplikasiaplikasi sejenis dan yang sudah ada sebelumnya dengan yang akan dikembangkan dalam penelitian ini. Untuk mendapatkan informasi dan petunjuk yang berguna bagi pengembangan aplikasi dalam penelitian ini.

b. Metode Perancangan

Untuk perancangan dan pengembangan aplikasi, digunakan Location Based Service (LBS) sebagai landasan dalam penelitian ini.

1) Preparing

Dalam pengembangan aplikasi ini sebaiknya terlebih dahulu melaku persiapan untuk menunjang dalam pembuatan aplikasi sebelum pekerjaan teknis untuk pembuatan aplikasi dimulai, hal ini penting untuk mengetahui sistem yang akan dibuat.

2) Planing

Berguna untuk mengatur kinerja pada software engineer, mengetahui soal resiko yang akan dihadapi nantinya, serta mengetahui apa saja sumber daya yang dibutuhkan, menghasilkan apa, serta yang terpenting adalah mengatur jadwal pembuatan perangkat lunak yang efektif.

3) Modeling

Tahapan ini berguna untuk sebuah model yang akan buat agar lebih memahami perangkat lunak atau sistem yang akan dipakai. Serta dengan tahap pemodelan, software enginer juga dapat lebih mengetahui desain perangakat lunak atau sistem agar dapat menyelesaikan masalah yang sedang berlangsung.

4) Contruction

Tahapan ini berguna untuk menggabungkan antara melakukan coding dan testing yang dibutuhkan dalam pembuatan suatu sistem untuk mengetahui kesalahan apa saja yang terdapat pada sistem atau perangkat lunak tersebut.

Perencanaan sistem informasi dan rute rumah sakit di Kota Kediri adalah kegiatan perencanaan berkelanjutan yang menjamin implementasi teknologi informasi dan komputasi. Secara umum bisa disimpulkan bahwa rancangan sistem terdiri dari tahapan-tahapan sebagai berikut:

1) Pengumpulan Data

Data yang dimaksud adalah data dan informasi rumah sakit di kota Kediri.

2) Studi Literatur

Mempelajari buku referensi dan jurnal yang berkaitan dengan permasalahan penelitian, serta mencari solusi yang terbaik. Topik bahasan utama yang dibutuhkan diantaranya adalah data rumah sakit, informasi yang berkaitan dengan pelayanan dan fasilitas utama rumah sakit.

3) Analisa

Melakukan uji coba secara teoritis terhadap masalah yang diangkat guna menganalisa apakah rancangan algoritma yang digunakan dapat menghasilkan solusi yang sesuai dengan tujuan penelitian.

4) Implementasi

Membuat program dari hasil rancangan algoritma, untuk mengimplementasikan serta membuktikan bahwa hasil analisa secara teoritis yang telah dilakukan benar-benar sesuai yang diharapkan.

5) Pengujian

Pengujian dilakukan untuk melihat apakah data yang telah menjadi input akan diproses sesuai dengan output yang diharapkan. Juga untuk mengevaluasi apakah rancangan sistem yang diusulkan mampu menjawab tujuan yang telah direncanakan.

6) Dokumentasi

Merupakan langkah akhir, penyusunan laporan mulai dari latar belakang permasalahan sampai dengan pengambilan kesimpulan.

\section{KAJIAN LITERATUR DAN DASAR TEORI 2.1 Kajian Literatur}

Ide perancangan dan pengembangan sistem informasi ini didukung juga oleh referensi beberapa penelitian sebelumnya, diantara penelitian yang dilakukan oleh Prameswari dan Dian Asihing, tahun 2014, dengan judul "Aplikasi Location Based Service SPBU Di Wilayah Bandung Tengah Berbasis Android". Dalam penelitian ini, penerapan Local Based Service (LBS) bertujuan untuk mempermudah pengguna jalan mencari lokasi SPBU terutama bagi wisatawan local yang berkunjung ke kota Bandung. Hasil pengujian pada penelitian ini menunjukan bahwa Location Based Service dapat digunakan untuk mencari lokasi SPBU di wilayah Bandung Tengah dan memiliki rincian fasilitas pada SPBU tersebut. Pencarian SPBU dapat dilakukan dengan memasukan alamat SPBU yang dituju atau 
melihat langsung pada peta yang sudah tersedia, dan pencarian berdasarkan lokasi terdekat dari user berada. Penelitian yang dilakukan oleh Budi Yulianto dan Rita Latona, tahun 2016 yang berjudul "Pencarian Rumah Makan Berbasis GPS pada Perangkat Mobile Android”. Tujuan Penelitian ini adalah merancang sebuah aplikasi untuk membantu pengguna melakukan pencarian rumah makan menggunakan GPS pada perangkat mobile android dan menghasilkan sebuah website yang digunakan untuk proses input, edit, delete seluruh informasi yang diperlukan aplikasi android kedalam database server. Penelitian yang dilakukan Fatimah Aljufri, tahun 2012 dengan judul "Sistem Pemandu Pencarian Masjid Terdekat Berbasis Lokasi Diatas Flatform Android". Sistem yang dibuat dalam penelitian adalah sebuah sistem yang mampu memberikan notifikasi bagi pengguna bahwa waktu sholat akan tiba. Selanjutnya sistem juga menampilkan lokasi pengguna dan lokasi masjid terdekat. Berdasarkan hasil pengujian sistem yang dilakukan, semua responden setuju bahwa aplikasi berfungsi sebagaimana mestinya.

\subsection{Dasar Teori}

Beberapa kajian teori dan dasar ilmu yang mendukung dalam penelitian ini adalah:

\section{a. Smartphone dan Android}

Smartphone menjadi generasi berikutnya dari komputasi bergerak (Mobile) yang akan mendorong konvergensi antara komunikasi, komputer dan pengguna perangkat elektronik, tiga ciri industri tradisional yang berbeda dengan interoperabilitas cukup rendah. Pada akhirnya, sebuahponsel pintar (smartphone) kemungkinan menjadi terminal bergerak universal (universal mobile terminal) dengan membawa fungsionalitas terpadu ditambah dengan mobilitas dan akses jaringan di mana-mana.

PcMag Encyclopedia memberikan definisi Smartphone sebagai sebuah telepon selular dengan built-in aplikasidan akses internet. Smartphone menyediakan layanan suara digital serta pesan teks, e-mail, web browsing, kamera dan video, pemutar musik dan video. Selain fungsi built-in yang ada, smartphone dapat menjalankan berbagai aplikasi, mengubah ponsel anda menjadi komputer bergerak (mobile computer).

Menurut Nasruddin Safaat H.(2012), android adalah sebuah sistem operasi pada handphone yang bersifat terbuka dan berbasis pada sistem operasi Linux. Android bisa digunakan oleh setiap orang yang ingin menggunakannya pada perangkat mereka. Android menyediakan platform terbuka bagi para pengembang untuk menciptakan aplikasi mereka sendiri yang akan digunakan untuk bermacam peranti bergerak.

\section{b. GPS (Global Position System)}

GPS (Global Position System) adalah sistem navigasi berbasiskan satelit yang saling berhubungan pada orbitnya. Satelit-satelit itu milik Departemen Pertahanan (Departemen of Defense) Amerika Serikat yang pertama kali diperkenalkan mulai tahun 1978 dan pada tahun 1994 sudah memakai 24 satelit.

Untuk dapat mengetahui posisi seseorang maka diperlukan alat yang diberinama GPS reciever yang berfungsi untuk menerima sinyal yang dikirim dari satelit GPS. Posisi diubah menjadi titik yang dikenal dengan nama Waypoint nantinya akan berupa titik-titik koordinat lintang dan bujur dari posisi seseorang atau suatu lokasi di layar pada peta elektronik.

Dengan teknologi GPS dapat digunakan untuk beberapa keperluan sesuai dengan tujuannya. GPS dapat digunakan oleh peneliti, olahragawan, petani, tentara, pilot, petualang, pendaki, pengantar barang, pelaut, kurir, penebang pohon, pemadam kebakaran dan orang dengan berbagai kepentingan untuk meningkatkan produktivitas, keamanan, dan untuk kemudahan.Dari beberapa pemakaiaan di atas dikategorikan menjadi:

1) Lokasi : Digunakan untuk menentukan dimana lokasi suatu titik dipermukaan bumi berada.

2) Navigasi : Membantu mencari lokasi suatu titik di bumi.

3) Tracking : Membantu untuk memonitoring pergerakan obyek.

4) Timing : Dapat dijadikan dasar penentuan jam seluruh dunia, karena memakai jam atom yang jauh lebih presesi dibanding jam biasa.

5) Membantu memetakan posisi tertentu, dan perhitungan jaringan terdekat.

\section{c. Location Based Service (LBS)}

Location Based Service (LBS) atau Layanan Berbasis Lokasi merupakan layanan informasi yang dapat diakses melalui perangkat mobile melalui jaringan selular dan memiliki kemampuan untuk memanfaatkan lokasi posisi perangkat mobile. Pengertian yang sama juga diberikan oleh Open Geospatial Consortium (OGC, 2005) mengenai LBS yaitu sebuah layanan IP (Internet Protocol) nirkabel yang menggunakan informasi geografis untuk memberikan layanan kepada pengguna perangkatmobile. Setiap layanan aplikasi yang memanfaatkan posisi terminal mobile (OGC, 2005). Location Based Service (LBS) adalah sebuah nama umum untuk sebuah layanan baru dimana informasi lokasi menjadi parameter utamanya (Kupper, 2005).

Pengertian lain, bahwa LBS sebenarnya salah satu nilai tambah dari layanan seluler GSM (Global System for Mobile). LBS bukanlah sistem, tetapi merupakan layanan yang menggunakan sistem tambahan penunjang sistem GSM (Global System for Mobile). Jadi jelas, beberapa opsi sistem yang dapat mengirim layanan LBS ini dengan teknologi bervariasi. Tetapi pada dasarnya, sistem-sistem tersebut menggunakan prinsip dasar yang sama, yaitu 
Triangulasi. Jadi prinsipnya, tidak jauh beda dengan sistem GPS, hanya saja fungsi satelit digantikan oleh BTS (Base Transceiver Station) (Riyanto, 2011).

Untuk menggambarkan cara kerja LBS, anggaplah aplikasi LBS akan mencarikan informasi mengenai lokasi rumah sakit yang berada di sekitar posisi kita sekarang. Anggaplah sekarang fungsi pencarian telah diaktifkan, posisi pengguna sebenarnya dari perangkat mobile diperoleh dari Positioning Service. Hal ini dapat dilakukan baik oleh perangkat menggunakan GPS sendiri atau layanan posisi jaringan yang berasal dari provider (Cell Tower). Setelah itu perangkat mobile pengguna mengirimkan permintaan informasi, yang berisi tujuan untuk mencari dan mengirimkan posisi melalui jaringan komunikasi ke gateway telekomunikasi.

Gateway memiliki tugas untuk bertukar pesan di antara jaringan komunikasi selular dan internet. Oleh karena itu dia tahu alamat web dari beberapa aplikasi server dan rute permintaan ke spesifik server tertentu. Gateway akan menyimpan juga informasi tentang perangkat mobile yang telah meminta informasi. Aplikasi server membaca permintaan dan mengaktifkan layanan yang terkait dalam kasus ini layanan pencarian.

Sekarang service menganalisis lagi pesan dan memutuskan mana informasi tambahan selain dari pencarian (rumah sakit) dan posisi pengguna diperlukan untuk menjawab permintaan pengguna. Dalam kasus iniservice akan menemukan bahwa pengguna membutuhkan informasi tentang rumah sakit dari database yellow pages pada wilayah tertentu dan kemudian service tersebut akan meminta penyedia data untuk memberika data tersebut.

Selanjutnya service akan menemukan bahwa informasi tentang jalan, jarak dan cara yang diperlukan untuk memeriksa apakah rumah sakit dapat dicapai (misalnya -kadang sebuah rumah sakit di sisi sungai lain mungkin tidak bisa dicapai karena tidak ada jembatan). Sekarang semua informasi service akan melakukan buffer spacial dan query routing untuk mendapatkan beberapa rumah sakit terdekat. Setelah menghitung daftar rumah sakit terdekat, hasil dikirim kembali ke pengguna melalui internet, gateway dan jaringan mobile.

Informasi mengenai rumah sakit akan disampaikan kepada pengguna baik sebagai daftar teks (disusun berdasarkan jarak) atau ditampilkan dalam peta. Setelah itu pengguna dapat meminta informasi lebih lanjut tentang rumah sakit (misalnya dokter dan fasilitas). serta dapat mengaktifkan pencarian rute untuk menuju rumah sakit tersebut.

\section{PEMBAHASAN}

Sistem aplikasi yang dibangun merupakan aplikasi berbasis sistem informasi dan peta lokasi untuk sistem bantu pencarian informasi rumah sakit di kota Kediri.

\subsection{Arsitektur Sistem}

Sistem aplikasi ini merupakan aplikasi berbasis sistem informasi dan peta lokasi untuk sistem bantu pencarian informasi rumah sakit di kota Kediri.

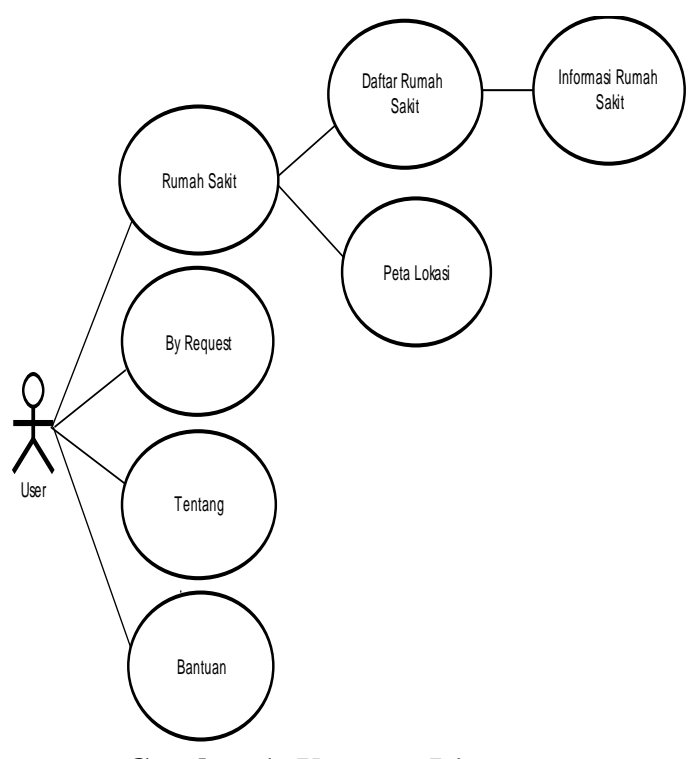

Gambar 1. Use case Diagram

Untuk menjelaskan arsitektur dari keseluruhan permasalahan yang dianalisa, maka dibuat suatu desain arsitektur dari kegiatan yang dilakukan tahap demi tahap.

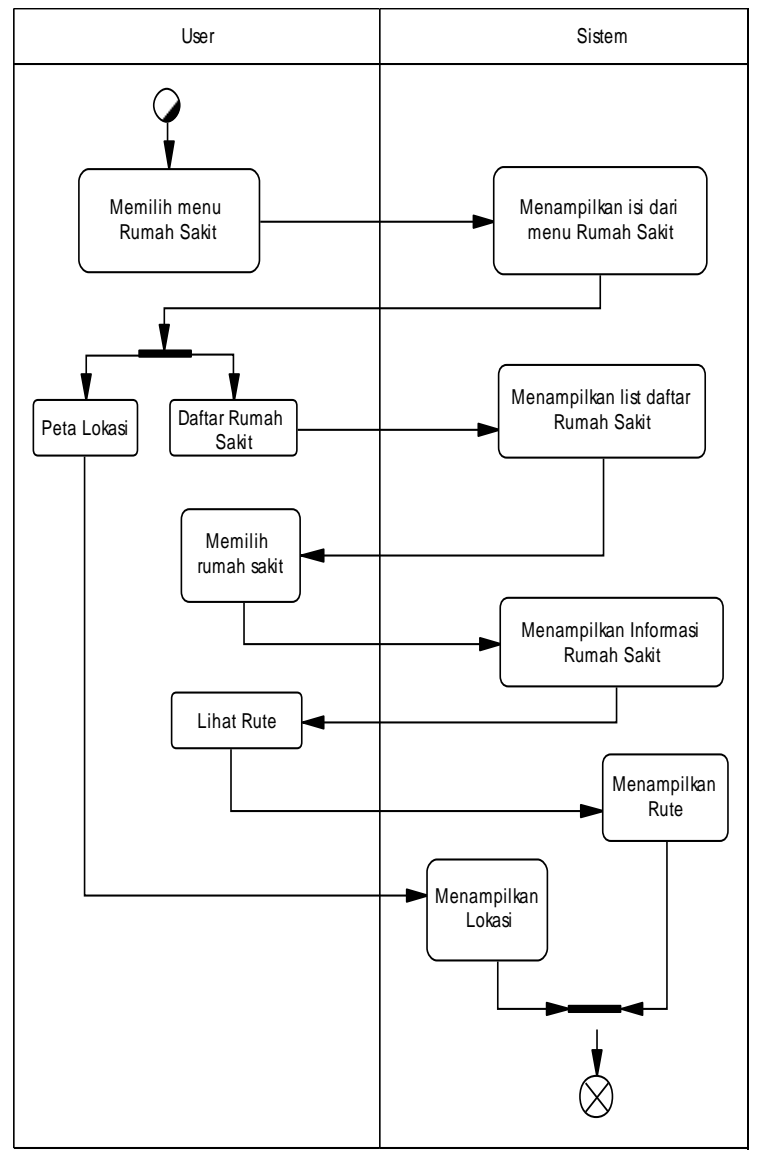

Gambar 2. Activity Diagram Rumah Sakit 
Secara sederhana pada awalnya telah disusun suatu desain sistem secara umum sebagaimana tersaji pada gambar 1, yang menggambarkan kegiatan yang dilakukan user dalam berinteraksi dengan aplikasi.

Pada gambar 2. Activity Diagram Rumah Sakit, dirancang user dapat memilih menu "Rumah Sakit", sistem akan menampilkan isi dari menu rumah sakit yaitu "Daftar Rumah Sakit" dan "Peta Lokasi". Jika user memilih menu "Daftar Rumah Sakit", maka sistem akan menampilkan list daftar rumah sakit. Ketika user memilih salah satu rumah sakit, maka sistem akan menampilkan informasi rumah sakit terpilih. Pada halaman informasi rumah sakit ini terdapat tombol yang digunakan untuk melihat rute. Ketika user menekan tombol rute, maka sistem akan menampilkan rute menuju rumah sakit. Jika user memilih peta lokasi, sistem akan menampilkan letak semua rumah sakit umum yang ada di Kota Kediri.

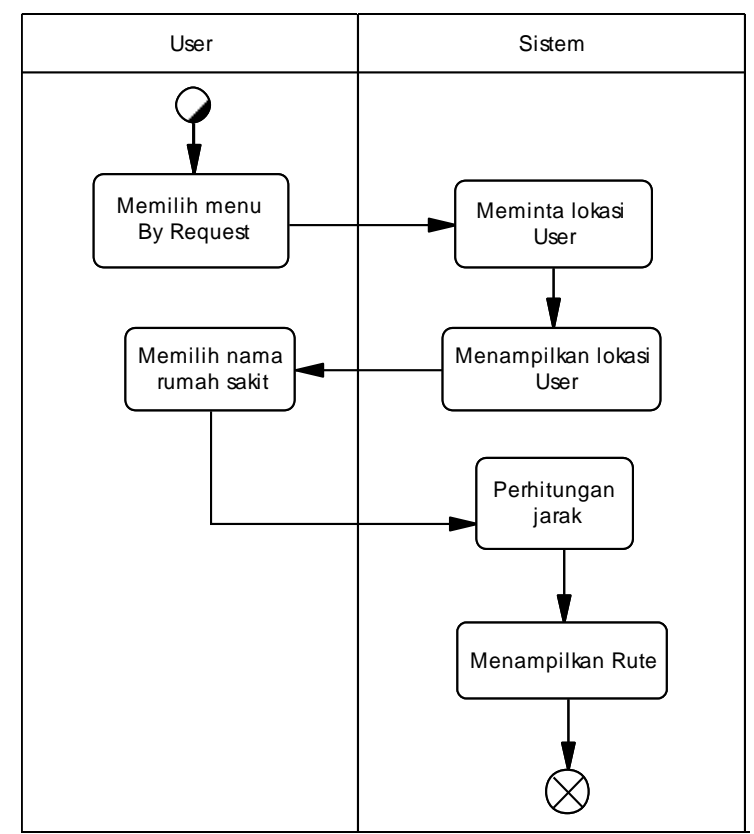

Gambar 3. Activity Diagram By Request

Pada gambar 3. Activity Diagram By Request, user dapat menggunakannya untuk memilih rumah sakit yang diinginkan. Ketika user memilih menu "By Request" sistem akan meminta posisi user untuk mengetahui lokasi user, setelah itu user memilih salah satu rumah lokasi rumah sakit. Setelah user memilih salah satu lokasi rumah sakit maka sistem akan menghitung jarak dan menampilkan rute menuju rumah sakit yang diinginkan user.

\subsection{Hasil dan Evaluasi}

Setelah selesainya tahap implementasi class dan antar muka aplikasi, maka dilakukan tahap pengujian aplikasi/ sistem yang sudah dibuat. Pengujian dilakukan terhadap beberapa point penting aplikasi. Pertama adalah pengujian instalasi aplikasi, kedua pengujian halaman html sebagai sumber informasi rumah sakit, ketiga pengujian penggunaan fungsi GPS untuk menentukan posisi awal, dan terakhir pengujian penggunaan fungsi penggambaran node/ simbol dan rute.

Dari beberapa kali pengujian yang dilakukan, didapat hasil sebagai berikut:

1) Pengujian Instalasi Aplikasi

Pada gambar 4. dapat diketahui bahwa aplikasi dapat diinstal pada android versi ice cream sandwich dan jelly bean.

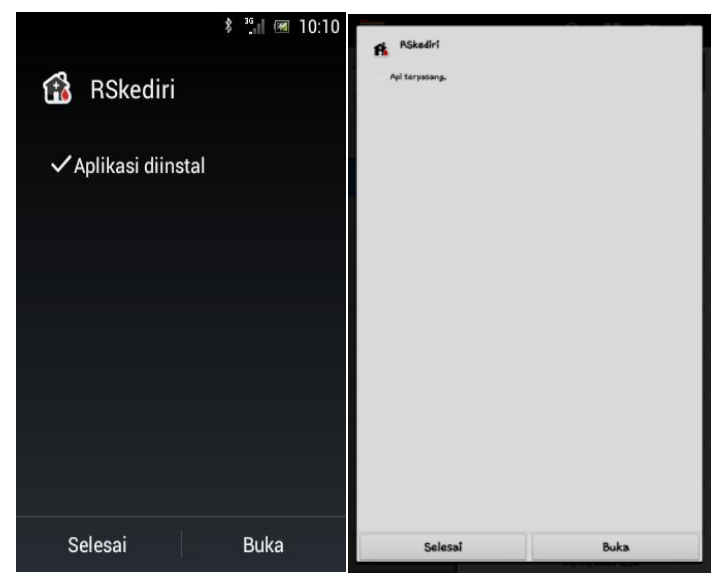

Gambar 4. Hasil Uji Instalasi Aplikasi

2) Hasil uji halaman html sebagai sumber informasi rumah sakit.
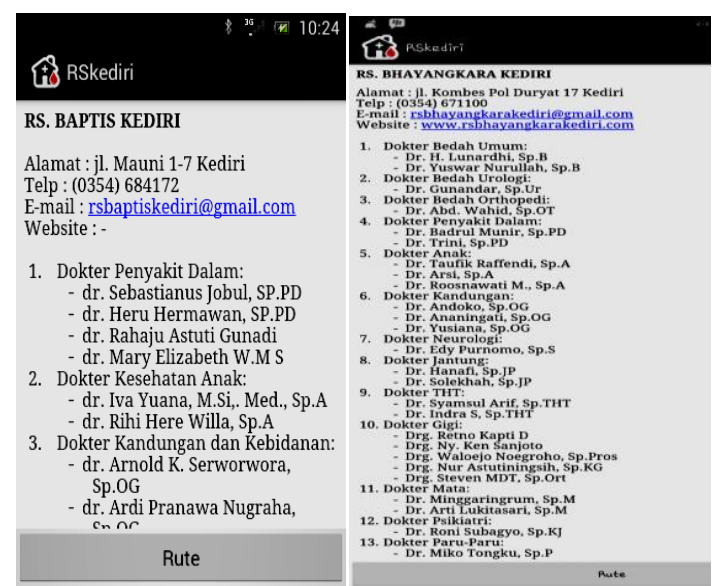

Gambar 5. Hasil Uji Halaman HTML

Pada gambar 5. di atas dapat diketahui bahwa sumber informasi berjenis file.html dapat menampilkan data informasi melalui halaman web view pada res/ layout project.

3) Hasil uji penggunaan fungsi GPS untuk menentukan posisi awal.

Untuk penggunaan class location listener dan location manager berjalan dengan sukses, sehingga dapat menunjukkan posisi user berdasarkan koordinat yang diambil dari perangkat GPS. Sesuai dengan yang ditunjukkan oleh gambar 6 . 

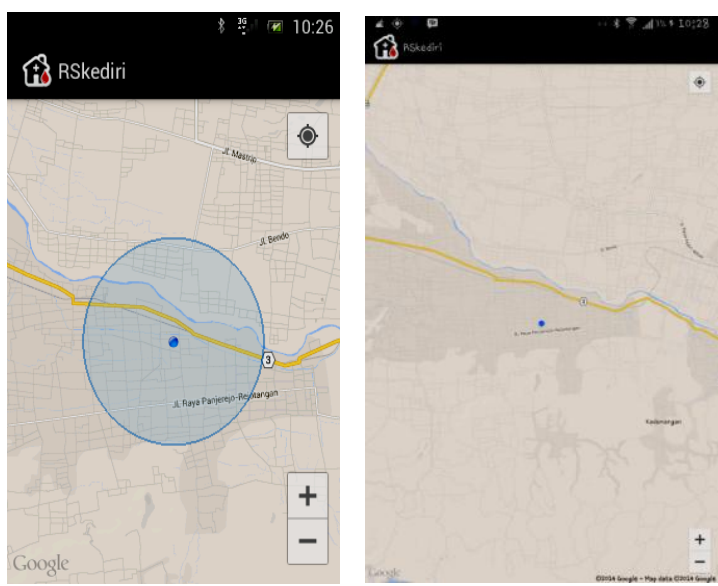

Gambar 6. Hasil Uji Fungsi GPS

4) Hasil uji penggunaan fungsi penggambaran node/ simbol dan rute.

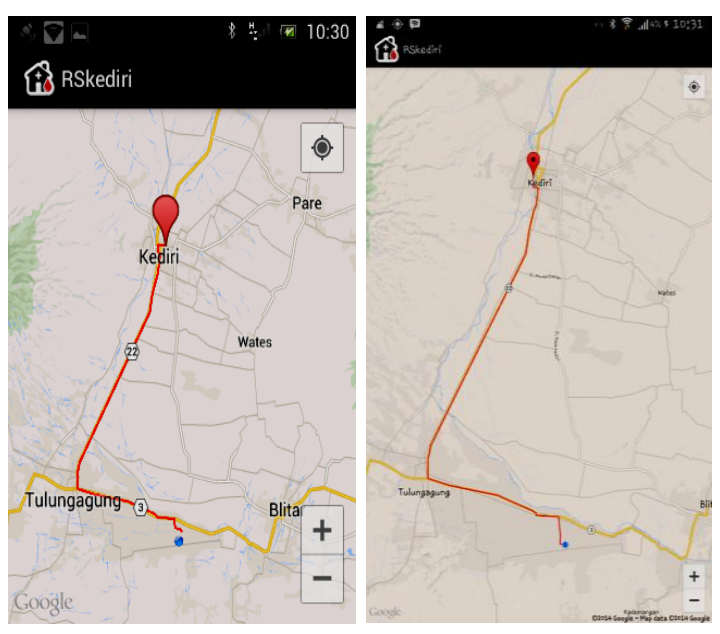

Gambar 7. Hasil Uji Fungsi Penggambaran Node

Pada gambar 7 di atas dapat diketahui bahwa class map overlay dan class route overlay dapat digunakan secara bersamaan. Dalam penggunaan class tersebut berjalan sukses dan dapat menampilkan rute menuju rumah sakit.

\subsection{Skenario Uji Coba Sistem}

Uji coba dilakukan pada smartphone android dengan versi sistem operasi android yang sesuai tabel. Uji coba ini bertujuan untuk mengetahui tingkat kompatibilitas masing-masing fungsi dari aplikasi, apakah aplikasi dapat berjalan sempurna dibeberapa versi android yang telah disebutkan. Hasil uji coba dapat dilihat pada tabel 1.

Tabel 1. Hasil Uji Coba

\begin{tabular}{|l|l|l|c|c|c|}
\hline \multirow{2}{*}{ Ujicoba } & \multicolumn{5}{|c|}{ Android Versi: } \\
\cline { 2 - 6 } & $\mathbf{4 . 0}$ & $\mathbf{4 . 0 . 3}$ & $\mathbf{4 . 1}$ & $\mathbf{4 . 2}$ & $\mathbf{4 . 3}$ \\
\hline Intalasi & OK & OK & OK & OK & OK \\
\hline Html & OK & OK & OK & OK & OK \\
\hline My Location & OK & OK & OK & OK & OK \\
\hline Rute & OK & OK & OK & OK & OK \\
\hline
\end{tabular}

Selanjutnya dilakukan pengujian Load Route. Pengujian ini berdasarkan waktu load route dari posisi user ke lokasi rumah sakit umum pada smartphone android secara acak sebanyak 10 kali dari lokasi awal yang berbeda.

Tabel 2. Data Posisi Pengujian Load Route

\begin{tabular}{|c|c|c|c|c|}
\hline \multicolumn{2}{|c|}{ PosisiAwal } & \multicolumn{2}{|c|}{ PosisiTujuan } & \multirow{2}{*}{$\begin{array}{c}\text { Nama } \\
\text { RSU }\end{array}$} \\
\hline Latitude & Longitude & Latitude & Longitude & \\
\hline-8.1287 & 112.033 & -7.8268 & 112.0322 & $\begin{array}{l}\text { RSU. } \\
\text { Baptis }\end{array}$ \\
\hline-8.1287 & 112.033 & -7.8133 & 112.0181 & $\begin{array}{l}\text { RSU. Bha- } \\
\text { yangkara }\end{array}$ \\
\hline-8.1287 & 112.033 & -7.8153 & 112.0062 & $\begin{array}{l}\text { RSU. } \\
\text { Gambiran }\end{array}$ \\
\hline-8.1287 & 112.033 & -7.8168 & 111.9894 & $\begin{array}{l}\text { RSU. } \\
\text { Lirboyo }\end{array}$ \\
\hline-8.1287 & 112.033 & -7.8229 & 111.9981 & RSU. Ratih \\
\hline
\end{tabular}

Posisi awal dengan koordinat -8.128774 , 11203319 adalah lokasi rumah penulis.

Tabel 3. Data Waktu Pengujian Load Route

\begin{tabular}{|c|c|l|c|}
\hline No & $\begin{array}{c}\text { Titik } \\
(\mathbf{x})\end{array}$ & \multicolumn{1}{|c|}{ Tujuan } & $\begin{array}{c}\text { Waktu } \\
\text { Load }\end{array}$ \\
\hline 1 & 1 & RSU. Baptis & 1.4 \\
\hline 2 & 1 & RSU. Bhayangkara & 1.2 \\
\hline 3 & 1 & RSU. Gambiran & 1.7 \\
\hline 4 & 1 & RSU. Lirboyo & 1.8 \\
\hline 5 & 1 & RSU. Ratih & 1.7 \\
\hline & $\mathbf{5}$ & Total waktu load route & $\mathbf{7 . 8}$ \\
\hline
\end{tabular}

Keterangan :

Titik (X) merupakan jumlah lokasi rumah sakit.

1) Analisa Hasil

Dalam pengujian ini dilakukan menggunakan smartphone sony xperia ST21i. Dari hasil pengujian di atas, kemudian dilakukan perhitungan nilai rata-rata yang diperlukan untuk load rute. Dalam hal ini menggunakan rumus untuk menghitung rata-rata yaitu:

rata - rata $=\frac{\sum f}{\sum x}$

Keterangan:

$\sum f=$ total nilai variabel $\mathrm{f}$

$\sum x=$ total nilai variable $\mathrm{x}$

Data perhitungan rumus menghitung rata-rata akan diambil dari tabel yang merupakan hasil pengujian waktu load rute, sehingga di dapatkan nilai: 


$$
\begin{aligned}
& \text { rata-rata }=\frac{\sum f}{\sum x} \\
& =\frac{7.8}{5}=1.56 \mathrm{detik}
\end{aligned}
$$

Berdasarkan dari perhitungan rumus di atas, dapat diambil kesimpulan bahwa waktu rata-rata yang diperlukan untuk melakukan load rute untuk setiap node membutuhkan waktu 1.56 detik.

\section{KESIMPULAN}

Berdasarkan hasil pengujian yang telah dilakukan dalam pembangunan sistem ini, dapat disimpulkan bahwa aplikasi yang dibangun dapat berfungsi dengan baik, antara lain dalam hal:

a) Dapat menampilkan informasi rute menuju rumah sakit di Kota Kediri.

b) Dapat mennampilkan rute menuju rumah sakit sesuai keinginan pengguna melalui menu "By Request".

c) Dapat memberikan informasi tentang rumah sakit seperti alamat, nomor telpon, e-mail, webside, nama dokter dan penyakit yang ditangani.

\section{PUSTAKA}

ArbieE. 2000. Pengantar Sistem Informasi Manajemen Edisi Ke-7, Jilid 1.Bina Alumni Indonesia. Jakarta.

Ardiansyah. Perancangan aplikasi system pencarian lokasi SPBU terdekat berbasis Android, 2010. http://thesis.binus.ac.id/Doc/Bab2 diakses 16 Desember 2016 pukul 18.29 WIB.

Harini, Dwi., Kasih, Patmi., 2017, Aplikasi Bantu Sistem Informasi dan Rute Rumah Sakit Di Kota Kediri dengan Local Based Service (LBS), SNATIKA, 2017. STIKI Malang.

http://sirs.buk.depkes.go.id/rsonline/Peta_list.php di akses 12 Desember 2016

http://ispytic.com/id/gps-phone-location.php diakses pada tanggal 12 Desember 2016

http://pmat.uad.ac.id/abu-jafar-muhammad-ibnmusa-al-khwarizmi di akses pada tanggal 18 Desember 2016 pukul 19.47 WIB.

http://website.informer.com/library.binus.ac.id diakses pada 22 Oktober 2016,14.40 WIB.

Irwanto, D. 2007. Perancangan Object Oriented Softwaew dengan UML. Yogyakarta. Penerbit Andi.

Policyalma-nac. 2004. Internet : A Star Pathfinding for Beginners. Dalam http://www.policyalmanac.org/games/aStarTutor ial.htm, 23 desember 2016, pukul 21.19.

Russel, Stuart J and Peter Norvig.Artificial Intelligence: A Modern Approach. New Jersey: Prentice Hall, 2003.

Safaat, N.H. 2012. PemrogramanAplikasi Smartphone dan Tablet PC Berbasis Android.Bandung. Informatika. http://www.opengeospatial.org/standards/olsdiakses 28 Juni 2017 pukul 10.24 WIB.

Riyanto. Sistem Informasi Geografis Berbasis Mobile. Yogyakarta: Gava Media, 2010.

-.Tutorial Android Location Based Service. http://www.twoh.co/category/tutorial/tutorialandroid-lbs/ (diakses 20 Agustus 2016 pukul 14.19 WIB).

-.Informasi Latitude dan Longitude. http://www.findlatitudeandlongitude.com/search es/ (9 September 2016 pukul 19.13 WIB).

-Tutorial Menampilkan Map API V2. http://www.twoh.co/mudengdroid-belajarandroid-bersama-twohs-enggineering/tutorialandroid-dengan-android-maps-google-maps/ (diakses tanggal 11 September 2016 pukul 11.47 WIB).

-Tutorial Marker Lokasi, http://dambasaputra.blogspot.com/2014/05/multi-marker-daninfo-windows-maps-api/ (diakses pada tanggal 3 Oktober 2016 pukul 09.51WIB).

http://www.json.org/ diakses pada tanggal 15 Oktober 2016 pukul 15.30 WIB. 